\title{
FAKTOR SUKSES (KEY SUCCESS FACTOR) KONTRAKTOR DALAM MENGIKUTI LELANG MENGGUNAKAN SISTEM E-PROCUREMENT DI KOTA LHOKSEUMAWE
}

\author{
M. Fauzan ${ }^{1)}$, Mukhlis ${ }^{2)}$, Evazavira ${ }^{3)}$ \\ 1), 2) Jurusan Teknik Sipil, ${ }^{3)}$ Alumni Jurusan Teknik Sipil, Universitas Malikussaleh \\ Email:vira_vaza@yahoo.co.id
}

\begin{abstract}
Abstrak
E-Procurement adalah proses pengadaan barang/jasa pemerintah yang pelaksanaannya dilakukan secara elektronik yang berbasis web/internet dengan memanfaatkan fasilitas teknologi komunikasi dan informasi yang meliputi pelelangan umum secara elektronik yang diselenggarakan oleh Layanan Pengadaan Secara Elektronik (LPSE). Kesuksesan kontraktor dalam mengikuti lelang secara e-procurement di kota Lhokseumawe ditentukan oleh faktor mengembangkan potensi dan sumber daya manusia, faktor memahami peraturan dan ketentuan hukum, faktor memanfaatkan penguasaan teknologi secara optimal, faktor memiliki infrastuktur yang memadai dan faktor mengadakan pengembangan sosialisasi. Dari hasil penelitian diperoleh perhitungan Cronbach Alpha 0,74 yang berarti kuesioner bisa digunakan sebagai alat mencapai tujuan penelitian. Dengan menggunakan program SPSS versi 17.0 for window diperoleh $r^{2}$ sebesar 0,755 ini berarti faktorfaktor tersebut berpengaruh terhadap kesuksesan kontraktor mengikui lelang secara e-procurement adalah sebesar 75,5\% dan diperoleh persamaan analisis regresi yaitu: $\mathrm{Y}=1,885+0,470 \mathrm{X}_{1}-0,204 \mathrm{X}_{2}+0,398 \mathrm{X}_{3}-0,002 \mathrm{X}_{4}-0,019 \mathrm{X}_{5}$ + ei, di mana faktor mengembangkan potensi dan sumber daya manusia $\left(X_{1}\right)$ faktor memanfaatkan penguasaan teknologi secara optimal $\left(\mathrm{X}_{3}\right)$ mempunyai pengaruh yang signifikan terhadap kesuksesan kontraktor, sedangkan faktor memahami peraturan dan ketentuan hukum $\left(\mathrm{X}_{2}\right)$, faktor memiliki infrastuktur yang memadai $\left(\mathrm{X}_{4}\right)$ dan faktor mengadakan pengembangan sosialisasi $\left(\mathrm{X}_{5}\right)$ tidak ada pengaruh yang signifikan terhadap kesuksesan kontraktor mengikui lelang secara e-procurement.
\end{abstract}

Kata Kunci: E-procurement, Faktor Sukses, Signifikan

\section{Pendahuluan}

Layanan Pengadaan Secara Elektronik (LPSE) atau sering disebut dengan $e$ procurement adalah unit layanan penyelenggara sistem elektronik pengadaan barang atau jasa yang didirikan oleh Kementerian/ Lembaga/ Perguruan Tinggi/ BUMN dan Pemerintah Daerah untuk memfasilitasi pejabat pengadaan atau Unit Layanan Pengadaan (ULP) dalam melaksanakan pengadaan barang atau jasa pemerintah secara elektronik.

Berdasarkan Peraturan Presiden No. 54 Tahun 2010, e-procurement ini dibentuk dengan tujuan untuk mencegah terjadinya manipulasi atau korupsi yang marak terjadi dalam ruang lingkup penyedia barang atau jasa. Selain itu, proses pengadaan barang atau jasa secara elektronik ini dapat meningkatkan efisiensi, efektifitas, transparansi, dan akuntabilitas, juga menjamin tersedianya informasi, kesempatan usaha, serta mendorong terjadinya persaingan yang sehat dan terwujudnya keadilan (non discriminative) bagi seluruh pelaku usaha yang bergerak di bidang pengadaan barang atau jasa pemerintah. 
Pengadaan barang atau jasa untuk pemerintah adalah salah satu alat untuk meningkatkan roda perekonomian. Maka, tidak heran bila kegiatan pengadaan barang dan jasa menjadi salah satu kegiatan pemerintahan yang banyak diminati oleh kalangan pengusaha yang bergerak dibidang barang atau jasa. Penerapan sistem lelang secara e-procurement di lingkungan instansi pemerintah memberikan tantangan tersendiri. Apalagi dengan kebijakan pemerintah yang terus menerus disempurnakan sehingga hal ini mempengaruhi suksesnya sebuah perusahaan, baik sukses dalam arti dapat mengaplikasikan lelang secara $e$ procurement sekaligus sukses mendapatkan kinerja proyek.

Mengingat kesuksesan kontraktor dalam mengikuti lelang secara $e$ procurement ditentukan oleh beberapa faktor yaitu: faktor mengembangkan potensi dan sumber daya manusia, faktor memahami peraturan dan ketentuan hukum, faktor memanfaatkan penguasaan teknologi secara optimal, faktor memiliki infrastuktur yang memadai dan faktor mengadakan pengembangan sosialisasi. Maka penulis tertarik melakukan penelitian terhadap faktor-faktor apakah yang paling berpengaruh atau signifikan terhadap kesuksesan kontraktor mengikuti lelang secara e-procurement.

\section{Tinjauan Kepustakaan}

Peraturan kepala lembaga kebijakan pengadaan barang jasa pemerintah nomor 1 tahun 2011 mendefinisikan e-procurement adalah metode pemilihan penyedia barang atau jasa pekerjaan konstruksi atau jasa lainnya secara elektronik untuk semua pekerjaan yang dapat diikuti oleh semua penyedia jasa lainnya yang memenuhi syarat. Aktivitas yang dilakukan oleh penyedia jasa konstruksi atau kontraktor dalam e-procurement (Peraturan Presiden No.54 Tahun, 2010), yaitu:

1. Pendaftaran penyedia;

Untuk dapat mengikuti lelang melalui Sistem Pengadaan Secara Elektronik (SPSE), terlebih dahulu publik (masyarakat umum yang termasuk di dalamnya perusahaan yang akan menjadi penyedia) harus mendaftar untuk menjadi penyedia. Pendaftaran ini dilakukan secara online dan offline. Pendaftaran secara online dilakukan pada website LPSE yaitu pada website http://lpse.lhokseumawekota.go.id/eproc/app. Kemudian setelah melakukan proses pendaftaran secara online, calon penyedia melakukan proses pendaftaran secara offline dengan datang langsung ke kantor LPSE setempat.

2. Melengkapi data penyedia;

Setelah user id dan password untuk akses ke situs LPSE lebih lanjut di dapat melaui email, maka akan tampil halaman yang berisi menu-menu khusus untuk penyedia. Kemudian penyedia di arahkan kepada proses melengkapi identitas data perusahaan penyedia seperti jenis izin perusahaan, nomor surat dari izin usaha, periode berlakunya surat izin usaha tersebut, instansi yang mengeluarkan izin usaha, kualifikasi perusahaan, klasifikasi jenis usaha yang dijalankan oleh perusahaan, akta perusahaan, struktur organisasi hingga peralatan yang dimiliki oleh perusahaan penyedia jasa.

3. Mendaftar untuk ikut lelang;

Untuk mendaftarkan perusahaan pada paket lelang, user perusahaan dapat mengakses pada website LPSE dan mencari jenis paket lelang sesuai kriteria perusahaan.

Faktor Sukses (Key Success Factor) Kontraktor Dalam Mengikuti Lelang Menggunakan Sistem e-Procurement di Kota Lhokseumawe -Fauzan, Mukhlis, Evazavira 
4. Mengunduh dokumen lelang;

Dokumen lelang dapat diunduh oleh user perusahaan apabila perusahaan dapat melewati proses evaluasi prakualifikasi. Kemudian secara internal perusahaan penyedia mempersiapkan strategi penawaran terbaik untuk dapat memenangkan tender yang diikuti tersebut.

5. Mengikuti penjelasan lelang (Aanwijzing);

Penjelasan mengenai paket lelang dapat dilihat oleh penyedia jasa pada website LPSE seperti metode pengadaan/penyelenggaraan pelelangan, cara penyampaian penawaran, metode evaluasi, sistem kontrak, dan hal-hal lain yang berkaitan dengan informasi paket lelang tersebut.

6. Mengirim dokumen kualifikasi;

Dokumen kualifikasi perusahaan penyedia jasa berupa dokumen izin usaha, dukungan bank, bukti pajak, tenaga ahli, pengalaman, pekerjaan yang sedang diikuti oleh perusahaan, peralatan, neraca dan akta perusahaan di upload via internet melalui website LPSE terkait.

7. Mengirim dokumen penawaran;

Setelah penyedia mempersiapkan semua dokumen-dokumen yang diperlukan untuk mengikuti lelang, maka user perusahaan penyedia dapat mengirimkan atau meng-upload dokumen via internet pada website LPSE untuk kemudian pihak panitia pelaksanaan paket lelang mengevaluasi seluruh dokumendokumen yang ada, yang di upload oleh para perusahaan penyedia jasa.

8. Melakukan sanggah;

Proses sanggah dilakukan secara online pada website LPSE apabila ada peserta yang merasa dirugikan atau ada hal-hal terkait lainnya yang dianggap tidak pantas dalam proses pelelangan.

9. Mengunggah tembusan sanggah banding.

Proses menggugah tembusan sanggah banding juga dilakukan secara online pada website LPSE.

Berikut adalah alur proses penyedia jasa konstruksi atau kontraktor dalam pelaksanaan e-procurement:

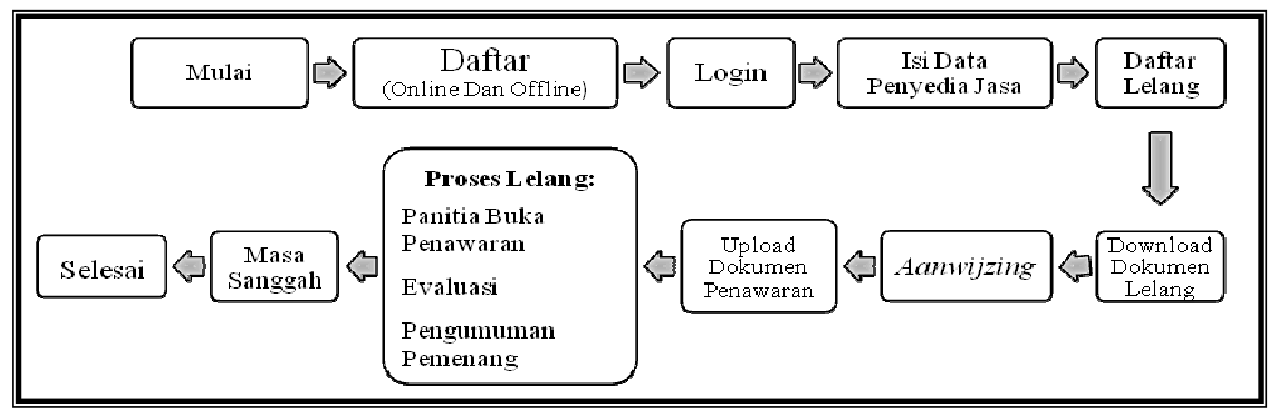

Gambar 1 Alur proses pelaksanaan e-procurement

Sumber: Petunjuk pengoperasian SPSE 3.2.2 (2011)

Menurut Hoskisson (2001), menyatakan bahwa proses manajemen strategi merupakan proses yang kritikal bagi kesuksesan suatu organisasi. Daya saing strategi dicapai ketika suatu perusahaan mengembangkan dan mengeksploitasikan keunggulan daya saing yang bertahan. 
Berdasarkan rumus, dapat dihitung jumlah sampel dari populasi mulai dari 10 sampai 1.000.000. besarnya taraf kesalahan bisa 1\%, 5\%, 10\%. Semakin besar taraf kesalahan maka akan semakin kecil jumlah sampel, begitu pula sebaliknya. Untuk menentukan berapa banyak anggota sampel, akan diambil dengan menggunakan rumus Slovin (Sugiyono, 2012) sebagai berikut:

$$
n=\frac{N}{1+N\left(e^{2}\right)}
$$

Keterangan:

$$
\begin{aligned}
\mathrm{n}= & \text { Jumlah sampel } \\
\mathrm{N}= & \text { Jumlah Populasi } \\
\mathrm{e}= & \text { Persen kelonggaran ketidaktelitian karena kesalahan pengambilan } \\
& \text { sampel yang masih dapat ditolerir }(1 \%, 5 \%, 10 \%) .
\end{aligned}
$$

Menurut Dawes John (2008) skala likert adalah suatu skala psikometrik yang umum digunakan dalam kuesioner, merupakan cara untuk mengukur sikap, pendapat dan persepsi seseorang atau sekelompok orang tentang fenomena sosial. Jawaban setiap item instrument yang menggunakan skala likert mempunyai gradasi dari sangat positif sampai sangat negatif, yang dapat berupa kata-kata dan diberi skor antara lain:

Tabel 1 Kriteria Interpretasi Skor

\begin{tabular}{|c|l|}
\hline Skor & \multicolumn{1}{|c|}{ Kriteria Interpretasi } \\
\hline 5 & Sangat setuju/sangat benar \\
4 & Setuju/benar \\
3 & Netral/Tidak tahu \\
2 & Tidak setuju/tidak benar \\
1 & Sangat tidak setuju/sangat tidak benar \\
\hline
\end{tabular}

Sumber: Dawes John, 2008

Menurut Vincentius (2009) kuisioner merupakan suatu teknik pengumpulan informasi yang memungkinkan analisis mempelajari sikap-sikap, keyakinan, perilaku dan karakteristik beberapa orang utama di dalam organisasi yang bisa terpengaruh oleh sistem yang diajukan atau oleh sistem yang sudah ada.

Langkah-langkah dalam penyusunan kuisioner adalah:

a. Merumuskan tujuan yang ingin dicapai oleh kuisioner,

b. Mengidentifikasikan variabel yang akan dijadikan sasaran kuisioner,

Menyebarkan setiap variabel menjadi sub variabel yang lebih spesifik dan tunggal, serta menentukan jenis data yang akan dikumpulkan dan teknik analisisnya.

Menurut Sugiyono (2012), validitas adalah tingkat keandalah dan kesahihan alat ukur yang digunakan. Instrumen dikatakan valid berarti menunjukkan alat ukur yang dipergunakan untuk mendapatkan data itu valid atau dapat digunakan untuk mengukur apa yang seharusnya di ukur. Analisis reliabilitas merupakan penerjemahan dari kata realibility yang artinya kepercayaan, keterhandalan, konsistensi dan sebagainya. Hasil pengukuran dapat dipercaya apabila dalam beberapa kali pengukuran terhadap kelompok subyek yang sama diperoleh hasil yang relatif sama, selama aspek yang diukur tidak berubah.

Faktor Sukses (Key Success Factor) Kontraktor Dalam Mengikuti Lelang Menggunakan Sistem e-Procurement di Kota Lhokseumawe-Fauzan, Mukhlis, Evazavira 
Reliabilitas instrumen adalah hasil pengukuran yang dapat dipercaya. Reliabilitas instrumen diperlukan untuk mendapatkan data sesuai dengan tujuan pengukuran. Untuk mencapai hal tersebut, dilakukan uji reliabilitas dengan menggunakan metode Cronbach Alpha diukur berdasarkan skala Cronbach Alpha 0 sampai 1. Adapun pengujian dengan menggunakan koefisien ini, harus lebih besar atau sama dengan 0,6 yaitu nilai yang dianggap dapat menguji valid tidaknya kuisioner. Untuk menguji instrumen digunakan rumus Alpha:

$r=\frac{k-1}{k} \quad\left[1-\frac{\sum \sigma_{b}{ }^{2}}{\sigma_{t}{ }^{2}}\right]$

Keterangan:

$\mathrm{r} \quad=$ reliabilitas instrumen

$\mathrm{k} \quad=$ banyaknya butir pertanyaan atau banyaknya soal

$\sum \sigma_{\mathrm{b}}{ }^{2}=$ jumlah varians butir

$\sigma_{\mathrm{t}}^{2}=$ varians soal

Rumus untuk varians butir dan varians total:

$$
\begin{aligned}
& \sigma_{t}^{2}=\left[\frac{\sum X t}{n}\right]-\left[\frac{\sum X t}{n}\right]^{2} \\
& \sigma_{\mathrm{b}}^{2}=\frac{J k i}{n}-\frac{J k s}{n^{2}}
\end{aligned}
$$

Keterangan:

Jki = jumlah kuadrat seluruh butir

Jks $=$ jumlah kuadrat subjek

$\mathrm{n} \quad$ = jumlah responden.

Narbuko dan Achmadi (2004) penelitian deskriptif yaitu penelitian yang berusaha untuk menuturkan pemecahan masalah yang ada sekarang berdasarkan data-data, dan juga menyajikan data, menganalisis dan menginterpretasi. Analisis deskriptif memberikan mean dan peringkat masing-masing parameter yang dibahas, dan disajikan dalam bentuk tabel. Rumus yang digunakan adalah:

$$
\mathrm{X}=\frac{x i}{n}
$$

Keterangan:

$$
\begin{array}{ll}
\mathrm{X} & =\text { rata-rata } \\
\mathrm{X}_{\mathrm{i}} & =\text { data yang diambil } \\
\mathrm{n} & =\text { jumlah data }
\end{array}
$$

Menurut Imam Gozali (2005) Statistical product and service solution (SPSS) adalah program analisis statistik kuesioner, kemampuan yang dapat diperoleh dari SPSS meliputi pemrosesan segala bentuk file data, modifikasi data, membuat tabulasi berbentuk distribusi frekuensi, analisis. Di bawah operasi Windows, SPSS menawarkan banyak kemudahan dalam pengoperasiannya, antara lain pada menu pull down dengan dialog box dan interface, memberikan perintah dan sub perintah analisis, serta menyajikan hasil analisis (Tim Statistika Elementer, 2007:1). Analisis data-data hasil penelitian diharapkan dapat disajikan secara deskriptif dengan lebih mudah dan informatif dalam berbagai bentuk seperti: teks, table, dan grafik. 
Sugiyono (2012) analisa regresi digunakan untuk memprediksikan seberapa jauh perubahan nilai variabel dependen, bila nilai variabel independen dimanipulasi, dirubah-rubah atau dinaik-naikkan. Analisis regresi ganda digunakan oleh peneliti, bila peneliti bermaksud meramalkan bagaimana keadaan (naik turunnya) variable dependen (peubah bebas), bila dua atau lebih variable independen sebagai faktor predictor dimanipulasi (dinaik turunkan nilainya). Hubungan antar variable biasanya dinyatakan dalam suatu model matematis (fungsi), misal: $y=f(x)$ di mana y merupakan variabel bergantung (dependent variable) atau biasa juga dikatakan sebagai variabel yang dipengaruhi (indikator) dan $x$ merupakan variabel bebas (independent variable) atau biasa juga disebut variabel yang mempengaruhi predictor. Sebagai ilustrasi, misalkan y $=\mathrm{A}+\mathrm{Bx}$, model tersebut dapat diartikan, bahwa nilai y akan bertambah sebesar B unit satuan untuk setiap $\mathrm{x}$ berubah sebesar 1 unit satuan. Adapun bentuk umum metode analisis regresi-linear berganda sebagai berikut:

$$
Y=A+B_{1} X_{1}+B_{2} X_{2}+\ldots . .+B_{z} X_{z}
$$

Keterangan:

$$
\mathrm{Y} \quad=\text { Peubah tidak bebas }
$$

$\mathrm{X}_{1} \ldots \mathrm{Xz}=$ Peubah bebas

$\mathrm{A} \quad=$ Konstanta

$\mathrm{B}_{1} \ldots \mathrm{Bz}=$ Koefisien regresi

\section{Metode Penelitian}

Untuk memperoleh data atau informasi, penulis mengumpulkan data dengan menggunakan cara field research. Filed research adalah pengumpulan data yang dilaksanakan secara langsung pada objek penelitian yang bertujuan untuk mengumpulkan data yang sifatnya nyata. Sedangkan data yang akan diperoleh dengan mengadakan serangkaian kegiatan yang meliputi:

a. Interview adalah suatu cara dalam pengumpulan data dalam penelitian ini dengan mengadakan wawancara secara langsung dengan pihak-pihak yang terkait.

b. Observasi adalah suatu cara pengumpulan data yang dilaksanakan dengan mengadakan pengamatan secara langsung dengan pihak-pihak yang terkait.

c. Kuisioner adalah suatu cara pengumpulan data dengan cara menyusun sejumlah pertanyaan. Item-item pertanyaan dirancang sedemikian rupa guna mendapatkan data yang reliabel dan valid. Pertanyaan tersebut diberikan dan diisi oleh responden yang menjadi sampel dalam penelitian ini.

Data primer adalah data yang diperoleh langsung dari sumber atau subyek penelitian data primer didapat dengan penyebaran kuisioner yang ditujukan kepada perusahaan kontraktor. Penyusunan pertanyaan kuisioner dilakukan berdasarkan hasil kajian literatur, dalam hal ini target kuisioner diberikan kepada kontraktor yang pernah mengikuti proses lelang di kota Lhokseumawe.

Data sekunder merupakan data yang diperlukan untuk melengkapi penelitian atau data yang diperoleh dalam bentuk sudah jadi dari suatu badan instansi tertentu dan data yang diperoleh dari studi literatur dengan berbagai buku referensi, jurnal maupun dari internet. Data sekunder ini diperoleh dengan 
merujuk data dari Gapensi, Aka, Akbarindo, Askoni, Aspeknas, Askonas, dan Apaksindo Kota Lhokseumawe pada tahun 2012.

Pengujian hipotesis menggunakan analisis regresi ini menggunakan langkah sebagai berikut:

1. Menentukan besarnya koefisien regresi dari persamaan regresi yang telah dijelaskan di atas.

2. Mencari nilai determinan $\left(\mathrm{r}^{2}\right)$ yang merupakan koefisien yang menunjukkan besarnya persentase hubungan variable bebas dengan variable terikat.

3. Melakukan uji $\mathrm{F}$ guna menentukan tingkat signifikan secara keseluruhan pada tingkat keyakinan (level of significant) sebesar 95\% diambil dari tarif kesalahan 5\%. Pengujian hipotesis dengan uji $\mathrm{F}$ dilakukan dengan pengambilan keputusan yang berdasarkan probabilitas yaitu:

jika probabilitas > 0,05 maka Ho diterima, H1 ditolak dan jika probabilitas < 0,05 maka Ho dan $\mathrm{H} 1$ diterima.

\section{Hasil dan Pembahasan}

Karakteristik responden yang dipilih pada penelitian ini adalah sebanyak 80 perusahaan yang menangani proyek konstruksi di kota Lhokseumawe pada tahun anggaran 2012. Responden dapat dikelompokkan atas: informasi tentang $e$ procurement diperoleh dari, tahun perusahaan aktif ikut lelang, besar persentase ikut lelang, dan tingkat perusahaan memenangkan lelang.

Tabel 2 karakteristik responden dan Daftar Pertanyaan

\begin{tabular}{|c|c|c|c|}
\hline No. & Pertanyaan & $\begin{array}{l}\text { Frekuensi } \\
\text { (Resp) }\end{array}$ & $\begin{array}{l}\text { Persentase } \\
(\%)\end{array}$ \\
\hline 1 & $\begin{array}{l}\text { Apakah anda mengetahui informasi } \\
\text { mengenai e-procurement? }\end{array}$ & & \\
\hline- & Ya & 80 & 100 \\
\hline- & Tidak & 0 & 0 \\
\hline No. & Pertanyaan & $\begin{array}{l}\text { Frekuensi } \\
(\text { Resp) }\end{array}$ & $\begin{array}{c}\text { Persentase } \\
(\%)\end{array}$ \\
\hline 2 & Jika iya, informasi diperoleh dari : & & \\
\hline - & Literatur asing & 8 & 10.00 \\
\hline - & Relasi bisnis & 49 & 61.25 \\
\hline- & Media massa & 16 & 20.00 \\
\hline- & Lain-lain & 7 & 8.75 \\
\hline 3 & Jika tidak, mengapa anda tidak mengetahuinya? & & \\
\hline- & Kurang informasi & & \\
\hline- & Lain-lain & & \\
\hline 4 & Perusahaan mulai aktif ikut lelang e-procurement & & \\
\hline- & Tahun 2010 & 20 & 25.00 \\
\hline- & Tahun 2011 & 25 & 31.25 \\
\hline- & Tahun 2012 & 35 & 43.75 \\
\hline- & Tahun 2013 & 0 & 0.00 \\
\hline 5 & $\begin{array}{l}\text { Besar persentase perusahaan anda mengikuti proses } \\
\text { lelang e-procurement dalam tahun anggaran 2010- } \\
2012 \text { ? }\end{array}$ & & \\
\hline- & $10-20 \%$ & 5 & 6.25 \\
\hline- & $30-40 \%$ & 5 & 6.25 \\
\hline- & $50-60 \%$ & 7 & 8.75 \\
\hline- & $70-80 \%$ & 27 & 33.75 \\
\hline- & $90-100 \%$ & 36 & 45.00 \\
\hline 6 & $\begin{array}{l}\text { Selama mengikuti lelang e-procurement berapa } \\
\text { persen tingkat kesuksesan perusahaan } \\
\text { memenangkan lelang? }\end{array}$ & & \\
\hline- & $10-20 \%$ & 9 & 11.25 \\
\hline- & $30-40 \%$ & 11 & 13.75 \\
\hline- & $50-60 \%$ & 14 & 17.50 \\
\hline- & $70-80 \%$ & 22 & 27.50 \\
\hline - & $90-100 \%$ & 24 & 30.00 \\
\hline
\end{tabular}

Faktor Sukses (Key Success Factor) Kontraktor Dalam Mengikuti Lelang Menggunakan Sistem e-Procurement di Kota Lhokseumawe -Fauzan, Mukhlis, Evazavira 
Berdasarkan Tabel 2 menunjukkan bahwa 80 responden (100\%) paham mengenai e-procurement, informasi yang diterima dari literatur asing dijawab oleh 8 responden $(10,00 \%)$, dari relasi bisnis 49 responden $(61,25 \%)$, dari media masa 16 responden $(20,00 \%)$, dan diikuti jawaban lain-lain 7 responden $(8,75 \%)$. Perusahaan mulai ikut lelang secara e-procurement lebih dominan pada tahun 2012 sebanyak 35 responden (43,75\%), tahun 2011 sebanyak 25 responden $(31,25 \%)$, tahun 2010 sebanyak 20 responden $(25,00 \%)$, sedangkan pada tahun 20130 responden $(0,00 \%)$. Besar persentase perusahaan mengikuti proses lelang e-procurement dalam tahun anggaran 2010-2012 yaitu frekuensi jawaban 10-20\% sebanyak 5 responden $(6,25 \%), 30-40 \%$ sebanyak 5 responden $(6,25 \%), 50-60 \%$ sebanyak 7 responden 8,75\%), 70-80\% sebanyak 27 responden $(33,75 \%)$, 90-100\% sebanyak 36 responden (45,00\%). Persentase tingkat kesuksesan perusahaan memenangkan lelang secara e-procurement yaitu frekuensi jawaban $10-20 \%$ sebanyak 11 responden $(13,75 \%), 30-40 \%$ sebanyak 9 responden $(11,25 \%), 50-60 \%$ sebanyak 14 responden $(17,50 \%), 70-80 \% 22$ responden $(27,50 \%)$, sedangkan $90-100 \% 24$ responden $(30,00 \%)$.

\subsection{Variabel terikat (dependent variable)}

Variable yang bertindak sebagai variable terikat (dependent variable), pada faktor-faktor sukses kontraktor mengikuti lelang secara e-procurement dapat dilihat pada tabel dibawah ini:

Tabel 3 Variabel terikat (dependent variable)

\begin{tabular}{|c|c|c|c|c|}
\hline No. & Pertanyaan & Pernyataan & $\begin{array}{c}\text { Frek. } \\
\text { (resp.) }\end{array}$ & $\begin{array}{c}\text { Persen } \\
(\%)\end{array}$ \\
\hline \multirow[t]{5}{*}{1} & \multirow{5}{*}{$\begin{array}{l}\text { Apakah faktor mengembangkan } \\
\text { potensi dan sumber daya manusia } \\
\text { dapat mempengaruhi kesuksesan } \\
\text { kontraktor dalam mengikuti lelang } \\
\text { menggunakan sistem e-procurement di } \\
\text { kota Lhokseumawe? }\end{array}$} & Sangat Setuju & 69 & 86.25 \\
\hline & & Setuju & 10 & 12.50 \\
\hline & & Netral & 1 & 1.25 \\
\hline & & Tidak Setuju & 0 & 0 \\
\hline & & Sangat Tidak Setuju & 0 & 0 \\
\hline \multirow[t]{5}{*}{2} & \multirow{5}{*}{$\begin{array}{l}\text { Apakah faktor memahami peraturan } \\
\text { dan ketentuan hukum dapat } \\
\text { mempengaruhi kesuksesan kontraktor } \\
\text { dalam mengikuti lelang menggunakan } \\
\text { sistem e-procurement di kota } \\
\text { Lhokseumawe? }\end{array}$} & Sangat Setuju & 48 & 60.00 \\
\hline & & Setuju & 17 & 21.25 \\
\hline & & Netral & 12 & 15.00 \\
\hline & & Tidak Setuju & 3 & 3.75 \\
\hline & & Sangat Tidak Setuju & 0 & 0 \\
\hline No. & Pertanyaan & Pernyataan & $\begin{array}{c}\text { Frek. } \\
\text { (resp.) }\end{array}$ & \begin{tabular}{|c|} 
Persen \\
$(\%)$
\end{tabular} \\
\hline \multirow[t]{5}{*}{3} & \multirow{5}{*}{$\begin{array}{l}\text { Apakah faktor memanfaatkan } \\
\text { penguasaan teknologi secara optimal } \\
\text { dapat mempengaruhi kesuksesan } \\
\text { kontraktor dalam mengikuti lelang } \\
\text { menggunakan sistem e-procurement di } \\
\text { kota Lhokseumawe? }\end{array}$} & Sangat Setuju & 58 & 72.50 \\
\hline & & Setuju & 16 & 20.00 \\
\hline & & Netral & 6 & 7.50 \\
\hline & & Tidak Setuju & 0 & 0 \\
\hline & & Sangat Tidak Setuju & 0 & 0 \\
\hline \multirow[t]{5}{*}{4} & \multirow{5}{*}{$\begin{array}{l}\text { Apakah faktor memiliki infrastuktur } \\
\text { yang memadai dapat mempengaruhi } \\
\text { kesuksesan kontraktor dalam } \\
\text { mengikuti lelang menggunakan sistem } \\
\text { e-procurement di kota Lhokseumawe? }\end{array}$} & Sangat Setuju & 56 & 70.00 \\
\hline & & Setuju & 12 & 15.00 \\
\hline & & Netral & 8 & 10.00 \\
\hline & & Tidak Setuju & 4 & 5.00 \\
\hline & & Sangat Tidak Setuju & 0 & 0 \\
\hline \multirow[t]{5}{*}{5} & \multirow{5}{*}{\begin{tabular}{|l|} 
Apakah faktor mengadakan \\
pengembangan sosialisasi dapat \\
mempengaruhi kesuksesan kontraktor \\
dalam mengikuti lelang menggunakan \\
sistem e-procurement di kota \\
Lhokseumawe?
\end{tabular}} & \begin{tabular}{|l|} 
Sangat Setuju \\
\end{tabular} & 47 & 58.75 \\
\hline & & Setuju & 12 & 15.00 \\
\hline & & Netral & 12 & 15.00 \\
\hline & & Tidak Setuju & 9 & 11.25 \\
\hline & & Sangat Tidak Setuju & 0 & 0 \\
\hline
\end{tabular}

Faktor Sukses (Key Success Factor) Kontraktor Dalam Mengikuti Lelang Menggunakan Sistem e-Procurement di Kota Lhokseumawe -Fauzan, Mukhlis, Evazavira 
Berdasarkan Tabel 3 dapat dijelaskan bahwa faktor sumber daya manusia dengan jawaban sangat setuju yaitu frekuensi jawaban 69 responden $(86,25 \%)$, diikuti jawaban setuju 10 responden $(12,50 \%)$, jawaban netral 1 responden $(1,30 \%)$, sedangkan jawaban tidak setuju dan sangat tidak setuju tidak ada jawaban $(0 \%)$. Faktor hukum yang menjawab sangat setuju yaitu frekuensi jawaban 48 responden $(60,00 \%)$, diikuti jawaban setuju 17 responden $(21,30 \%)$, jawaban netral 12 responden $(15,00 \%)$, jawaban tidak setuju 3 responden $(3,80 \%)$, sedangkan sangat tidak setuju tidak ada jawaban (0\%). Faktor kemampuan teknologi dengan jawaban sangat setuju yaitu frekuensi jawaban 58 responden $(72,50 \%)$, diikuti jawaban setuju 16 responden (20,00\%), sedangkan jawaban netral 6 responden $(7,50 \%)$, sedangkan tidak setuju dan sangat tidak setuju tidak ada jawaban $(0 \%)$. Faktor kondisi infrastruktur dengan jawaban sangat setuju yaitu frekuensi jawaban 56 responden $(70,00 \%)$, diikuti jawaban setuju 12 responden $(15,00 \%)$, jawaban netral 8 responden $(10,00 \%)$, jawaban tidak setuju 4 responden $(5,00 \%)$, dan sangat tidak setuju tidak ada jawaban $(0 \%)$. Faktor sosialisasi dengan jawaban sangat setuju yaitu frekuensi jawaban 47 responden $(58,75 \%)$, diikuti jawaban setuju 12 responden $(15,00 \%)$, sedangkan jawaban netral 12 responden $(15,00 \%)$, tidak setuju 9 responden $(11,30 \%)$, dan sangat tidak setuju tidak ada jawaban $(0 \%)$.

\subsection{Variabel bebas (independent variable)}

Faktor mengembangkan potensi dan sumber daya manusia adalah orangorang yang terlibat dalam pelaksanaan e-procurement perlu memiliki kapasitas dan pengetahuan yang memadai agar dapat berperan sesuai dengan fungsinya masing masing dalam pelaksanaan lelang atau tender.

Tabel 4 Faktor mengembangkan potensi dan sumber daya manusia

\begin{tabular}{|c|c|c|c|c|}
\hline No. & Pertanyaan & Pernyataan & $\begin{array}{c}\text { Frek. } \\
\text { (resp.) }\end{array}$ & $\begin{array}{c}\text { Persen } \\
(\%)\end{array}$ \\
\hline \multirow[t]{5}{*}{1} & \multirow{5}{*}{$\begin{array}{l}\text { Setujukah anda keberhasilan } \\
\text { pelaksanaan lelang secara } \\
\text { e-procurement salah satunya } \\
\text { ditentukan oleh kesiapan sumber } \\
\text { daya manusia, baik secara kuantitas } \\
\text { (jumlah) maupun kualitas (kapasitas } \\
\text { dan integritas)? }\end{array}$} & Sangat Setuju & 31 & 38.75 \\
\hline & & Setuju & 29 & 36.25 \\
\hline & & Netral & 16 & 20.00 \\
\hline & & Tidak Setuju & 4 & 5.00 \\
\hline & & Sangat Tidak Setuju & 0 & 0 \\
\hline \multirow[t]{5}{*}{2} & \multirow{5}{*}{$\begin{array}{l}\text { Bagaimana tingkat kualifikasi setiap } \\
\text { personil pada perusahaan anda saat } \\
\text { ini? }\end{array}$} & Sangat Baik & 32 & 40.00 \\
\hline & & Baik & 22 & 27.50 \\
\hline & & Netral & 13 & 16.25 \\
\hline & & Tidak Baik & 12 & 15.00 \\
\hline & & Sangat Tidak Baik & 1 & 1.25 \\
\hline \multirow[t]{5}{*}{3} & \multirow{5}{*}{$\begin{array}{l}\text { Setujukah anda dengan pernyataan } \\
\text { bahwa kontraktor harus memiliki } \\
\text { daya kreatif yang tinggi dalam } \\
\text { memecahkan masalah mengenai } \\
\text { lelang? }\end{array}$} & \begin{tabular}{|l} 
Sangat Setuju \\
\end{tabular} & 19 & 23.75 \\
\hline & & Setuju & 23 & 28.75 \\
\hline & & \begin{tabular}{|l|} 
Netral \\
\end{tabular} & 18 & 22.50 \\
\hline & & Tidak Setuju & 16 & 20.00 \\
\hline & & Sangat Tidak Setuju & 4 & 5.00 \\
\hline
\end{tabular}

Berdasarkan Tabel 4 lebih dominan menjawab sangat setuju keberhasilan pelaksanaan lelang secara e-procurement ditentukan oleh kesiapan sumber daya manusia frekuensi jawaban sangat setuju 31 responden $(38,80 \%)$, diikuti jawaban setuju 29 responden $(36,30 \%)$, jawaban netral 16 reponden $(20,00 \%)$, tidak setuju 
4 responden $(5,00 \%)$, dan sangat tidak setuju $(0 \%)$. Perusahaan mempersiapkan personil yang memiliki kualifikasi yang tinggi lebih dominan menjawab sangat benar 32 responden (40,00\%), jawaban benar sebanyak 22 responden $(27,50 \%)$, jawaban tidak tahu 13 responden $(16,30 \%)$, tidak benar 12 responden $(15,00 \%)$, dan sangat tidak benar 1 responden $(1,30 \%)$. Setiap kontraktor harus memiliki daya kreatif yang tinggi dalam memecahkan masalah mengenai lelang frekuensi jawaban sangat setuju 19 responden $(23,80 \%)$, diikuti jawaban setuju 23 responden $(28,80 \%)$, jawaban netral 18 reponden $(22,50 \%)$, tidak setuju 16 responden $(20,00 \%)$, dan sangat tidak setuju 4 responden $(5,00 \%)$.

\subsection{Faktor memahami peraturan dan ketentuan hukum}

Faktor memahami peraturan dan ketentuan hukum adalah peraturan perundangan yang dapat dijadikan acuan dalam penyelenggaraan transaksi elektronik untuk menjamin keabsahan pelaksanaan transaksi. Dalam variable ini responden menilai sejauh mana faktor tersebut mempengaruhi kesuksesan kontraktor mengikuti lelang e-procurement.

Tabel 5 Faktor memahami peraturan dan ketentuan hukum

\begin{tabular}{|c|c|c|c|c|}
\hline No. & Pertanyaan & Pernyataan & $\begin{array}{l}\text { Frek. } \\
\text { (resp.) }\end{array}$ & $\begin{array}{c}\text { Persen } \\
(\%)\end{array}$ \\
\hline \multirow{5}{*}{ 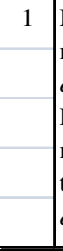 } & \multirow{5}{*}{$\begin{array}{l}\text { Menurut anda apakah benar ntuk } \\
\text { mendukung pelaksanaan } \\
\text { e-procurement di kota Lhokseumawe, } \\
\text { Pemerintah Daerah harus } \\
\text { mengeluarkan peraturan resmi tentang } \\
\text { tata cara pelaksanaan } \\
\text { e-procurement? }\end{array}$} & Sangat Benar & 41 & 51.25 \\
\hline & & Benar & 26 & 32.50 \\
\hline & & Tidak Tahu & 5 & 6.25 \\
\hline & & Tidak Benar & 8 & 26.67 \\
\hline & & Sangat Tidak Benar & 0 & 0 \\
\hline No. & Pertanyaan & Pernyataan & \begin{tabular}{|l} 
Frek. \\
(resp.)
\end{tabular} & $\begin{array}{c}\text { Persen } \\
(\%)\end{array}$ \\
\hline \multirow[t]{5}{*}{2} & \multirow{5}{*}{$\begin{array}{l}\text { Bagaimanakah tingkat pemahaman } \\
\text { anda terhadap hukum terkait } \\
\text { pelelangan secara } \text { e-procurement }\end{array}$} & Sangat Baik & 44 & 55.00 \\
\hline & & Baik & 28 & 35.00 \\
\hline & & \begin{tabular}{|l|} 
Tidak Tahu \\
\end{tabular} & 7 & 8.75 \\
\hline & & Tidak Baik & 1 & 1.25 \\
\hline & & Sangat Tidak Baik & 0 & 0 \\
\hline \multirow[t]{5}{*}{3} & \multirow{5}{*}{$\begin{array}{l}\text { Menurut anda apakah benar untuk } \\
\text { mudah memenangkan lelang } \\
\text { kontraktor harus berpedoman pada } \\
\text { peraturan pemerintah? }\end{array}$} & Sangat Benar & 36 & 45.00 \\
\hline & & Benar & 32 & 40.00 \\
\hline & & \begin{tabular}{|l} 
Tidak Tahu \\
\end{tabular} & 9 & 11.25 \\
\hline & & \begin{tabular}{|l|} 
Tidak Benar \\
\end{tabular} & 3 & 3.75 \\
\hline & & Sangat Tidak Benar & 0 & 0 \\
\hline
\end{tabular}

Berdasarkan Tabel 5 lebih dominan menjawab sangat benar dengan frekuensi jawaban 41 responden $(51,30 \%)$, diikuti jawaban benar 26 responden $(32,50 \%)$, jawaban tidak tahu 5 responden $(6,30 \%)$, tidak benar 8 responden $(10,00 \%)$ dan sangat tidak benar tidak ada jawaban $(0 \%)$. Kontraktor mudah mengikuti proses lelang harus berpedoman pada peraturan pemerintah responden menjawab sangat benar sebanyak 44 responden $(55,00 \%)$ diikuti jawaban benar 28 responden $(35,00)$, tidak tahu 7 responden $(8,80 \%)$, tidak benar 1 responden $(1,30 \%)$ dan sangat tidak benar tidak ada jawaban $(0 \%)$. Pemahaman kontraktor terhadap hukum menjawab sangat baik 36 responden $(45,00 \%)$, diikuti jawaban baik 32 responden $(40,00 \%)$, jawaban tidak tahu 9 responden $(11,30 \%)$, tidak baik 3 responden $(3,80 \%)$, dan sangat tidak baik tidak ada jawaban $(0 \%)$. 


\subsection{Faktor memanfaatkan penguasaan teknologi secara optimal}

Penguasaan teknologi yang dimaksud adalah penyelengaraan transaksi melalui media elektronik, pembangunan sistem e-registrasi untuk penyedia jasa, kapasitas bandwitch yang cukup untuk kelancaran proses pengisian format-format pelelangan/ tender, upload dan unggah dokumen, serta keamanan sistem aplikasi dan dokumen dari serangan virus atau hacker.

Tabel 6 Faktor memanfaatkan penguasaan teknologi secara optimal

\begin{tabular}{|c|c|c|c|c|}
\hline No. & Pertanyaan & Pernyataan & $\begin{array}{c}\text { Frek. } \\
\text { (resp.) }\end{array}$ & $\begin{array}{c}\text { Persen } \\
(\%)\end{array}$ \\
\hline \multirow[t]{5}{*}{1} & \multirow{5}{*}{$\begin{array}{l}\text { Bagaimana tingkat kemampuan anda } \\
\text { dalam menggunakan teknologi? }\end{array}$} & Sangat Baik & 37 & 46.25 \\
\hline & & Baik & 21 & 26.25 \\
\hline & & Netral & 21 & 26.25 \\
\hline & & Tidak Baik & 1 & 1.25 \\
\hline & & Sangat Tidak Baik & 0 & 0 \\
\hline \multirow[t]{5}{*}{2} & \multirow{5}{*}{\begin{tabular}{|l|} 
Menurut anda apakah benar \\
kelancaran proses lelang secara \\
e-procurement harus didukung oleh \\
pelayanan teknologi secara ideal?
\end{tabular}} & Sangat Benar & 45 & 56.25 \\
\hline & & Benar & 27 & 33.75 \\
\hline & & Tidak Tahu & 2 & 2.50 \\
\hline & & Tidak Benar & 6 & 7.50 \\
\hline & & \begin{tabular}{|l|} 
Sangat Tidak Benar \\
\end{tabular} & 0 & 0 \\
\hline \multirow[t]{5}{*}{3} & \multirow{5}{*}{$\begin{array}{l}\text { Bagaimana tingkat kemampuan anda } \\
\text { dalam menghadapi gangguan } \\
\text { terhadap peralatan elektronik? }\end{array}$} & Sangat Baik & 45 & 56.25 \\
\hline & & Baik & 33 & 41.25 \\
\hline & & Netral & 2 & 2.50 \\
\hline & & Tidak Baik & 0 & 0 \\
\hline & & \begin{tabular}{|l} 
Sangat Tidak Baik \\
\end{tabular} & 0 & 0 \\
\hline
\end{tabular}

Berdasarkan Tabel 6 yang menjawab sangat benar memiliki kemampuan menggunakan teknologi dengan baik 37 responden (46,30\%), diikuti jawaban benar 21 responden $(26,30 \%)$, jawaban tidak tahu 21 reponden $(26,30 \%)$, tidak benar 1 responden $(1,30 \%)$ dan sangat tidak benar $(0 \%)$. Kelancaran proses lelang e-procurement harus didukung oleh pelayanan teknologi secara ideal lebih dominan menjawab sangat benar 45 responden $(56,30 \%)$, jawaban benar sebanyak 27 responden $(33,80 \%)$, tidak tahu 2 responden $(2,50 \%)$, tidak benar 6 responden $(7,50 \%)$ sedangkan sangat tidak benar tidak ada jawaban $(0 \%)$. Kontraktor memiliki kemampuan dalam menghadapi gangguan terhadap peralatan elektronik frekuensi jawaban sangat penting 45 responden $(56,30 \%)$, diikuti jawaban penting 33 responden $(41,30 \%)$, jawaban tidak tahu 2 responden $(2,50 \%)$, sedangkan tidak penting dan sangat tidak penting $(0 \%)$.

\subsection{Faktor memiliki infrastuktur yang memadai}

Faktor infrastruktur adalah sarana yang diperlukan dalam mendukung pelayanan e-procurement secara ideal seperti gedung LPSE dan beberapa fasilitas yang dibutuhkan. penyiapan hardware dan software dan beberapa fasilitas yang dibutuhkan antara lain, perangkat komputer, administrator, untuk klien, maupun untuk training serta menyiapkan back-up data yang selalu identik dengan server induk disertai instalasi software (sistem aplikasi server), penyiapan jaringan telepon dan fax, pemasangan jaringan LAN/ internet local area.

Berdasarkan Tabel 6 yang menjawab sangat benar fasilitas jaringan internet dan fasilitas pendukung yang memadai mempermudah dalam mengikuti lelang dengan frekuensi jawaban 31 responden (38,80\%), diikuti jawaban benar 44 responden $(55,00 \%)$, jawaban tidak tahu 5 reponden $(6,30 \%)$, sedangkan tidak benar dan sangat tidak benar tidak ada jawaban $(0 \%)$. Sangat penting mengupdate perubahan sistem terbaru dijawab sebanyak 57 responden $(71,30 \%)$ penting 
sebanyak 12 responden $(15,00 \%)$ diikuti jawaban netral 10 responden $(12,50 \%)$, tidak penting 1 responden $(1,30 \%)$ sedangkan sangat tidak penting tidak ada jawaban $(0 \%)$. Pihak terkait memiliki prosedur kerja yang baik dominan menjawab sangat benar 42 responden $(52,50 \%)$, diikuti jawaban benar 10 responden $(12,50 \%)$, sedangkan jawaban tidak tahu 25 responden $(31,30 \%)$, tidak benar 3 responden $(3,80 \%)$ sedangkan sangat tidak benar $(0 \%)$.

Tabel 7 Faktor memiliki infrastuktur yang memadai

\begin{tabular}{|c|c|c|c|c|}
\hline No. & Pertanyaan & Pernyataan & $\begin{array}{l}\text { Frek. } \\
\text { (resp.) }\end{array}$ & $\begin{array}{c}\text { Persen } \\
(\%)\end{array}$ \\
\hline \multirow[t]{5}{*}{1} & \multirow{5}{*}{$\begin{array}{l}\text { Apakah fasilitas jaringan internet dan } \\
\text { fasilitas pendukung yang memadai } \\
\text { mempermudah anda dalam mengikuti } \\
\text { lelang? }\end{array}$} & Sangat Benar & 31 & 38.75 \\
\hline & & Benar & 44 & 55.00 \\
\hline & & Tidak Tahu & 5 & 6.25 \\
\hline & & Tidak Benar & 0 & 0 \\
\hline & & Sangat Tidak Benar & 0 & 0 \\
\hline \multirow[t]{5}{*}{2} & \multirow{5}{*}{$\begin{array}{l}\text { Bagaimana penataan sistem } \\
\text { manajemen perusahaan anda saat in? }\end{array}$} & \begin{tabular}{|l|} 
Sangat Baik \\
\end{tabular} & 57 & 71.25 \\
\hline & & Baik & 12 & 15.00 \\
\hline & & Netral & 10 & 12.50 \\
\hline & & Tidak Baik & 1 & 1.25 \\
\hline & & Sangat Tidak Baik & 0 & 0 \\
\hline \multirow[t]{5}{*}{3} & \multirow{5}{*}{$\begin{array}{l}\text { Apakah pelaksanaan e-procurement } \\
\text { akan berjalan sukses apabila pihak } \\
\text { terkait memiliki prosedur kerja yang } \\
\text { baik? }\end{array}$} & \begin{tabular}{|l} 
Sangat Benar \\
\end{tabular} & 42 & 52.50 \\
\hline & & Benar & 10 & 12.50 \\
\hline & & Tidak Tahu & 25 & 31.25 \\
\hline & & Tidak Benar & 3 & 3.75 \\
\hline & & Sangat Tidak Benar & 0 & 0 \\
\hline
\end{tabular}

\subsection{Faktor mengadakan pengembangan sosialisasi}

Mengadakan Sosialisasi adalah memberikan informasi/ data pelelangan/ tender kepada publik/ masyarakat layanan pengadaan secara elektronik yang didukung oleh administrator, trainer, helpdesk, dan verifikator. Dalam pengelolaan LPSE idealnya perlu dibentuk unit kelembagaan tersendiri yang tugasnya memberikan layanan pengadaan barang atau jasa secara elektronik di lingkup wilayah instansinya masing-masing.

Tabel 8 Faktor mengadakan pengembangan sosialisasi

\begin{tabular}{|c|c|c|c|c|}
\hline No. & Pertanyaan & Pernyataan & $\begin{array}{c}\text { Frek. } \\
\text { (resp.) }\end{array}$ & $\begin{array}{c}\text { Persen } \\
(\%)\end{array}$ \\
\hline \multirow[t]{5}{*}{1} & \multirow{5}{*}{$\begin{array}{l}\text { Setujukah anda bahwa sosialisasi } \\
\text { bukan hanya ditujukan kepada } \\
\text { masyarakat jasa konstruksi, tetapi } \\
\text { juga kepada masyarakat umum dan } \\
\text { LSM yang berkecimpung terhadap } \\
\text { proses lelang e-procurement? }\end{array}$} & Sangat setuju & 45 & 56.25 \\
\hline & & Setuju & 19 & 23.75 \\
\hline & & Netral & 6 & 7.50 \\
\hline & & Tidak Setuju & 8 & 10.00 \\
\hline & & Sangat Tidak Setuju & 2 & 2.50 \\
\hline \multirow[t]{5}{*}{2} & \multirow{5}{*}{$\begin{array}{l}\text { Menurut anda apakah benar selain } \\
\text { dengan sosialisasi pemerintah juga } \\
\text { perlu mengadakan pelatihan } \\
\text { e-procurement kepada penyedia } \\
\text { jasa konstruksi? }\end{array}$} & Sangat Benar & 58 & 72.50 \\
\hline & & Benar & 19 & 23.75 \\
\hline & & \begin{tabular}{|l|} 
Tidak Tahu \\
\end{tabular} & 3 & 3.75 \\
\hline & & Tidak Benar & 0 & 0 \\
\hline & & Sangat Tidak Benar & 0 & 0 \\
\hline \multirow[t]{5}{*}{3} & \multirow{5}{*}{$\begin{array}{l}\text { Setujukah anda kontraktor harus } \\
\text { melakukan kegiatan pensosialisasian } \\
\text { secara lebih luas dan lebih gencar } \\
\text { lagi dengan pihak-pihak terlibat } \\
\text { lelang agar mudah memenangkan } \\
\text { lelang? }\end{array}$} & Sangat setuju & 57 & 71.25 \\
\hline & & Setuju & 18 & 22.50 \\
\hline & & Netral & 4 & 5.00 \\
\hline & & Tidak Setuju & 1 & 1.25 \\
\hline & & Sangat Tidak Setuju & 0 & 0 \\
\hline
\end{tabular}

Berdasarkan Tabel 8 sosialisasi bukan hanya ditujukan kepada masyarakat jasa konstruksi, tetapi juga kepada masyarakat umum dan LSM frekuensi jawaban sangat setuju 45 responden $(56,30 \%)$, jawaban setuju sebanyak 19 responden 
$(23,80 \%)$, jawaban netral 6 responden $(7,50 \%)$, tidak setuju 8 responden $(10,00 \%)$ dan sangat tidak setuju 2 responden $(2,50 \%)$. Pelatihan-pelatihan e-procurement yang diselenggarakan oleh pemerintah termasuk salah satu kemudahan bagi kontraktor menjawab sangat benar 58 responden $(72,50 \%)$, diikuti jawaban benar 19 responden $(23,80 \%)$, jawaban tidak tahu 3 responden $(3,80 \%)$, sedangkan tidak benar dan sangat tidak benar tidak ada jawaban $(0 \%)$. Kontraktor harus melakukan pensosialisasian secara lebih luas dan lebih gencar lagi dengan pihakpihak terlibat lelang menjawab sangat setuju 57 responden $(71,30 \%)$, diikuti jawaban setuju 18 responden $(22,50 \%)$, jawaban netral 4 responden $(5,00 \%)$, tidak setuju 1 responden $(1,3 \%)$ sedangkan sangat tidak setuju tidak ada jawaban $(0 \%)$.

\subsection{Regresi}

Regresi faktor-faktor sukses kontraktor dalam mengikuti lelang secara $e$ procurement di kota Lhokseumawe. Hasil Perhitungan analisis regresi

Tabel 9 Hasil regresi faktor-faktor yang mempengaruhi kesuksesan kontraktor dalam mengikuti lelang secara e-procurement di kota Lhokseumawe.

\begin{tabular}{|c|c|c|}
\hline Variabel & Koefisien & Significant \\
\hline Konstant & 1,885 & 0,000 \\
$X_{1}$ & 0,470 & 0,000 \\
$X_{2}$ & $-0,204$ & 0,066 \\
$X_{3}$ & 0,398 & 0,000 \\
$X_{4}$ & $-0,002$ & 0,987 \\
$X_{5}$ & & 0,905 \\
\hline \multirow{2}{*}{$\mathrm{DF}=80-5-1=74$} & $\mathrm{R}=0,869$ & \multirow{2}{*}{ Fsig $=0,000$} \\
\hline
\end{tabular}

Berdasarkan hasil pengolahan data, tabel diatas dapat dilihat koefisien dari masing-masing variable dan konstanta yang menjadi observasi penelitian ini adalah koefisien $X_{1}(0,470)$, koefisien $X_{2}(-0,204)$, koefisien $X_{3}(0,398)$, koefisien $X_{4}(-0,002)$, koefisien $X_{5}(0,019)$, dan konstanta 1,885 . Secara persamaan dapat ditulis sebagai berikut :

$$
\begin{aligned}
& Y=a+b_{1} X_{1}+b_{2} X_{2}+b_{3} X_{3}+b_{4} X_{4}+b_{5} X_{5}+e i \\
& Y=1,885+0,470 X_{1}-0,204 X_{2}+0,398 X_{3}-0,002 X_{4}-0,019 X_{5}+e i
\end{aligned}
$$

Dari persamaan tersebut dijelaskan bahwa faktor-faktor yang mempengaruhi kesuksesan kontraktor dalam mengikuti lelang secara e-procurement di kota Lhokseumawe yaitu mengembangkan potensi dan sumber daya manusia, faktor memahami peraturan dan ketentuan hukum, faktor memanfaatkan penguasaan teknologi secara optimal, faktor memiliki infrastuktur yang memadai dan faktor mengadakan pengembangan sosialisasi. Hasil analisis menunjukkan bahwa:

a. Konstanta (a) sebesar 1,885 yang merupakan nilai tetap, hal ini menyatakan bahwa tidak ada faktor mengembangkan potensi dan sumber daya manusia, faktor memahami peraturan dan ketentuan hukum, faktor memanfaatkan penguasaan teknologi secara optimal, faktor memiliki infrastuktur yang 
memadai dan faktor mengadakan pengembangan sosialisasi yang dapat mempengaruhi suksesnya kontraktor mengikuti lelang secara e-procurement.

b. Faktor mengembangkan potensi dan sumber daya manusia $\left(\mathrm{X}_{1}\right)$ sebesar $(0,470)$, hal ini menyatakan bahwa setiap peningkatan faktor mengembangkan potensi sumber daya manusia sebesar 1 satuan orang (kontraktor), maka akan meningkatkan kesuksesan kontraktor mengikuti lelang sebesar $47 \%$.

c. Faktor memahami peraturan dan ketentuan hukum $\left(\mathrm{X}_{2}\right)$ sebesar $(-0,204)$, hal ini menyatakan bahwa jika terjadi penurunan faktor memahami peraturan dan ketentuan hukum sebesar -1 satuan orang (kontraktor), maka akan menurunkan kesuksesan kontraktor mengikuti lelang sebesar 20,4\%.

d. Faktor memanfaatkan penguasaan teknologi secara optimal $\left(\mathrm{X}_{3}\right)$ sebesar $(0,398)$, hal ini menyatakan bahwa setiap peningkatan memanfaatkan penguasaan teknologi sebesar 1 satuan orang (kontraktor), maka akan meningkatkan kesuksesan kontraktor mengikuti lelang sebesar 39,8\%.

e. Faktor memiliki infrastuktur yang memadai $\left(\mathrm{X}_{4}\right)$ sebesar $(-0,002)$, hal ini menyatakan bahwa jika terjadi penurunan faktor memiliki infrastruktur yang memadai sebesar -1 satuan orang (kontraktor), maka akan menurunkan kesuksesan kontraktor mengikuti lelang sebesar $0,2 \%$.

f. Faktor mengadakan pengembangan sosialisasi $\left(X_{5}\right)$ sebesar $(-0,019)$, hal ini menyatakan bahwa jika terjadi penurunan faktor mengadakan pengembangan sosialisasi sebesar -1 satuan orang (kontraktor), maka akan menurunkan kesuksesan kontraktor mengikuti lelang sebesar 1,9\%.

Selanjutnya untuk mengetahui ada tidaknya hubungan atau kuat lemahnya hubungan antara variabel faktor mengembangkan potensi dan sumber daya manusia, faktor memahami peraturan dan ketentuan hukum, faktor memanfaatkan penguasaan teknologi secara optimal, faktor memiliki infrastuktur yang memadai dan faktor mengadakan pengembangan sosialisasi terhadap kesuksesan kontraktor mengikui lelang e-procurement dapat dilihat dari koefisien korelasi (r) diperoleh $\mathrm{r}$ hasil sebesar $(0,869)$ atau $86,9 \%$, nilai ini menunjukkan bahwa hubungan kelima variabel penelitian ada dikategori kuat dan positif. Kemudian diperoleh nilai $\mathrm{R}$ square $r^{2}=(0,755)$, ini berarti faktor-faktor tersebut memiliki pengaruh kontribusi terhadap kesuksesan kontraktor mengikui lelang e-procurement adalah sebesar $75,5 \%$ dan sisanya $24,5 \%$ dipengaruhi oleh faktor-faktor lain diluar variable penelitian (error term).

Menetukan tingkat signifikan secara keseluruhan pada tingkat kepercayaan sebesar 95\% dengan pengujian hipotesis dengan uji $\mathrm{F}$ yaitu diperoleh Fsig sebesar 0,000 berarti $0,000<0,05$ maka $H_{0}$ ditolak dan $H_{i}$ diterima sehingga secara simultan variable independen faktor mengembangkan potensi dan sumber daya manusia, faktor memahami peraturan dan ketentuan hukum, faktor memanfaatkan penguasaan teknologi secara optimal, faktor memiliki infrastuktur yang memadai dan faktor mengadakan pengembangan sosialisasi berpengaruh secara signifikan terhadap kesuksesan kontraktor mengikui lelang e-procurement. Berdasarkan persamaan regresi yang diperoleh dapat dijelaskan sebagai berikut:

1. Faktor mengembangkan potensi dan sumber daya manusia $\left(X_{1}\right)$ probalitas hitung sebesar 0,000 lebih kecil dari 0,05 , maka ini berpengaruh secara 
signifikan terhadap kesuksesan kontraktor mengikui lelang e-procurement, sehingga hipotesis $H_{0}$ ditolak dan $H_{i}$ diterima.

2. Faktor memahami peraturan dan ketentuan hukum $\left(X_{2}\right)$ probalitas hitung 0,066 lebih kecil dari 0,05, maka faktor ini tidak berpengaruh secara signifikan terhadap kesuksesan kontraktor mengikui lelang e-procurement, sehingga hipotesis $H_{0}$ diterima dan $H_{i}$ ditolak.

3. Faktor memanfaatkan penguasaan teknologi secara optimal $\left(X_{3}\right)$ probalitas hitung 0,000 lebih kecil dari 0,05, maka faktor ini berpengaruh secara signifikan terhadap kesuksesan kontraktor mengikui lelang e-procurement, sehingga hipotesis $H_{0}$ ditolak dan $H_{i}$ diterima.

4. Faktor memiliki infrastuktur yang memadai $\left(X_{4}\right)$ probalitas hitung 0,987 lebih kecil dari 0,05 , maka factor ini tidak berpengaruh secara signifikan terhadap kesuksesan kontraktor mengikui lelang e-procurement, sehingga hipotesis $H_{0}$ diterima dan $H_{i}$ ditolak.

5. Faktor mengadakan pengembangan sosialisasi $\left(X_{\mathrm{5}}\right)$ probalitas hitung 0,905 lebih kecil dari 0,05, maka faktor ini tidak berpengaruh secara signifikan terhadap kesuksesan kontraktor mengikui lelang e-procurement, sehingga hipotesis $H_{0}$ diterima dan $H_{i}$ ditolak.

\subsection{Kesimpulan}

Berdasarkan hasil perhitungan dan pembahasan mengenai faktor sukses kontraktor dalam mengikuti lelang secara e-procurement maka dapat disimpulkan:

1. Faktor-faktor yang mempengaruhi kesuksesan kontraktor mengikuti lelang secara e-procurement terdiri dari: faktor mengembangkan potensi dan sumber daya manusia, faktor memanfaatkan penguasaan teknologi secara optimal menunjukkan adanya pengaruh (signifikan). Sedangkan faktor memahami peraturan dan ketentuan hukum, faktor memiliki infrastuktur yang memadai dan faktor mengadakan pengembangan sosialisasi tidak adanya pengaruh (signifikan) terhadap kesuksesan.

2. Penggunaan kuisioner sebagai alat penelitian dengan mengacu pada nilai-nilai yang diperoleh terhadap faktor-faktor yang mempengaruhi kesuksesan kontraktor mengikuti lelang secara e-procurement yang ditinjau masingmasing mempunyai nilai sebesar 0,74 . Nilai-nilai tersebut merupakan syarat minumun dari kolom Cronbach Alpha.

3. Variabel dan konstanta yang menjadi observasi penelitian adalah faktor mengembangkan potensi dan sumber daya manusia $\left(X_{1}\right)$ sebesar 0,470 , faktor memanfaatkan penguasaan teknologi secara optimal $\left(X_{2}\right)$ sebesar $-0,204$, faktor memahami peraturan dan ketentuan hukum $\left(\mathrm{X}_{3}\right)$ sebesar 0,398, faktor memiliki infrastuktur yang memadai $\left(\mathrm{X}_{4}\right)$ sebesar $-0,002$, faktor mengadakan pengembangan sosialisasi $\left(\mathrm{X}_{5}\right)$ sebesar 0,019, dan konstanta 1,885.

4. Koefisien korelasi (r) hasil sebesar $86,9 \%$, yang berarti hubungan antara kelima faktor faktor ada dikategori penelitian kuat dan positif. Sedangkan koefisien determinan $\left(r^{2}\right)=$ sebesar $75,5 \%$ yang dapat ditafsirkan bahwa variabel bebas $\mathrm{X}$ memiliki kontribusi sebesar $75,5 \%$ terhadap variabel $\mathrm{Y}$ dan sisanya $24,5 \%$ dipengaruhi oleh factor-faktor lain diluar variabel penelitian (error term). 


\section{Daftar Kepustakaan}

Azwar, Saifuddin, 2000, Reliabilitas dan Validitas, Pustaka Pelajar, Yogyakarta.

Dawes, J, 2008, Buku Ajar, CV. Sindunata, Bandung.

Djojosoekarto 2008, Dimensi Penerapan Sukses E-Procurement, available from internet (http://www.evaluasi penerapan e-procurement.com/).

Falih2009, Aspek Sukses Pelaksanaan E-Procurement, available from internet (http://www.scribd.penerapan e-procurement.com/).

Ghozali Imam, 2005, Analisis Multivariate dengan Program SPSS, Tarsono, Semarang.

Hoskisson, R.E, 2001, Manajemen Strategi, Salemba Empat, Jakarta.

Narbuko, C., Dan Ahmadi, A., 2004, Metodelogi Penelitian, Bumi Aksara, Jakarta.

Pemerintah Republik Indonesia, 2010, Peraturan Presiden No.54 tahun 2010 Tentang pedoman Pelaksanaan Pengadaan Barang dan Jasa Pemerintah.

Sugiyono, 2012, Statistika untuk Penelitian, Alfabeta, Bandung.

Vincentius, 2009, Panduan Belajar dan Evaluasi, Grasindo, Jakarta. 